\title{
Skin Papilloma
}

National Cancer Institute

\section{Source}

National Cancer Institute. Skin Papilloma. NCI Thesaurus. Code C4614.

A benign papillary neoplastic growth on the skin composed of epithelial cells and a fibrous stalk. It usually develops in the eyelid, axilla, neck, upper chest, and groin. 